\title{
The role of listening comprehension in dictation
}

\author{
Parya Habibi ${ }^{1}$, Azadeh Nemati ${ }^{2 *}$ and Sharmin Habibi ${ }^{3}$ \\ ${ }^{1}$ Young Researchers Club, Islamic Azad University, Sanandaj Branch, Sanandaj, Iran \\ ${ }^{2}$ Department of English language teaching, Jahrom branch, Islamic Azad University, Jahrom, Iran, \\ ${ }^{3}$ Young Researchers Club, Islamic Azad University, Sanandaj Branch, Sanandaj, Iran \\ paryahabibi@yahoo.com, azadehnematiar@yahoo.com*, Habibi.sharmin@yahoo.com
}

\begin{abstract}
A cursory look at most students in Kurdistan is ample to show that the role of listening comprehension in dictation, as an integral part of language learning, has often been overlooked in the development of EFL curriculum. To conduct the study 80 students were selected from Islamic Azad University, Sanandaj Branch. They were divided into groups A and $B$ and were taught dictation in two different ways. For group $A$ it was done traditionally while for group $B$ it was in accordance with processing listening comprehension and improving listening. The result of ANCOVA revealed that group B leads to higher performance in dictation.
\end{abstract}

Keywords: Listening comprehension, Dictation, Standard dictation, Trans-dictation, Dicto-comp.

\section{Introduction}

It is believed that teaching a foreign language and dictation is not limited to learning vocabularies and structures. Having discussed the importance of comprehension and listening the questions of how to teach dictation in EFL situations is raised. According to Celce - Murcia et al. (1997) there are two basic types of student responses in listening exercises: A) The question-oriented response model that is students are asked to listen to an oral text, then answer a series of factual comprehension questions on the content, B) The task- oriented response model that is students make use of the information provided in the spoken text, not as an end in itself but as a resource to use. The study of listening comprehension becomes a polestar of second language theory building research and pedagogy (Anderson \& Lynch, 1988).

Up to know, comprehension based approaches to instruction may vary mightily in how educator try to render the listening comprehension; they are similar in their lessened emphasized on formal dictation analysis. Listening comprehension has attracted the least attention among all the dictations, in terms of both the amount of research conducted on the text and the neglect that it suffered in most student programs. For a language learner to be a proficient partner in any dictation, need to be skillful at both comprehension and listening, so in order to make the students be more competent in writing skills of language, course designers have devoted most of their time to generating exercises on teaching listening and comprehension in tandem. Rivers (1981) points out that the lack of attention to listening has no scientific reasons. Chastain (1988) asserts that because listening is an unobservable and abstract process, it is overlooked by teachers. It is believed that listening process is currently gaining attention as a major area of interest in the literature of second/foreign language learning (Bacon, 1989; Johnson, 1995).

Listening comprehension enables learners to function successfully in second language community. Celce-Murcia and McIntosh (1981) believe that the aim of listening comprehension is to make learners understand the language used by native speakers. They believe that in language teaching and learning, the important principles that determine the norms of appropriate language use within the framework of the listening represent comprehension.

Chauldron and Richards (1986) make a distinction between the two processes in listening: namely, bottomup and top-down. Bottom-up processing: the use of incoming data as a reference of information about the meaning of a message and comprehension process begins with the message received until the intended meaning is arrived at. Top-down processing is the use of background knowledge in understanding the meaning of a message. In fact the bulk of research since the mid-90' has especially focused on finding various foreign / second language instruction methods to integrate dictation instruction within a listening framework. Pursuing this trend, many researchers have attempted to define the teacher center approach to explicit dictation instruction.

Regarding dictation, Parrot (1993) suggests that listening is a very valuable source of dictation practice. Dictation can be used as both a writing practice when the teacher is willing to employ a procedure for reproduction and as a listening practice when he / she wants to make students listen with attention as much as they can, so that they would write down what they have heard. Chiang (1995) stated that dictation should be substituted for many other languages. Listening has been at the heart of the debate in dictation and subject to controversy and discussion among researchers of the field for at least 40 years.

Dictation is divided into five groups, including standard dictation, partial dictation, elicited imitation, dicto-comp, and dictation with competing noise. Standard dictation, defined as a passage of appropriate length and difficulty. The passage is read, and then students write down what they hear and then the students get the result of passage. Second they listen to the passage in parts and write down what they get. Third, in the partial dictation, a passage with some deleted section is given, 
and then reading entirely. The students listen and fill in the deleted parts. Forth the students listen and imitation in elicited imitation, Fifth Dicto-comp is used when students listen to a passage and write down what they have comprehended. Sixth in dictation with competing noise, hearing when an extra noise is in the background. The subjects are expected to know the passage. Seventh in trans-dictation, a passage is read loudly, and the students translate it in their native tongues. In all kinds of dictation, comprehension is unavoidable skill.

There is no explicit relationship between listening and specialization of knowledge in dictation. Chaudron and Richards (1986) enumerate several factors that can hinder listening comprehension, such as of personal internal factors, inattentiveness, personal disinterest in the topic, etc. (Fig.1).

In the process of dictation, one aspect that emerges as a topic of discussion is the relationship between the listening comprehension and the dictation from which that language is originated. Most scholars focus on comprehension as an integral part of dictation learning. Therefore, the following hypothesis was made.

Does listening comprehension instruction affect dictation score of experimental group comparing control group?

Fig. 1. The interrelation of comprehension, listening comprehension and dictation

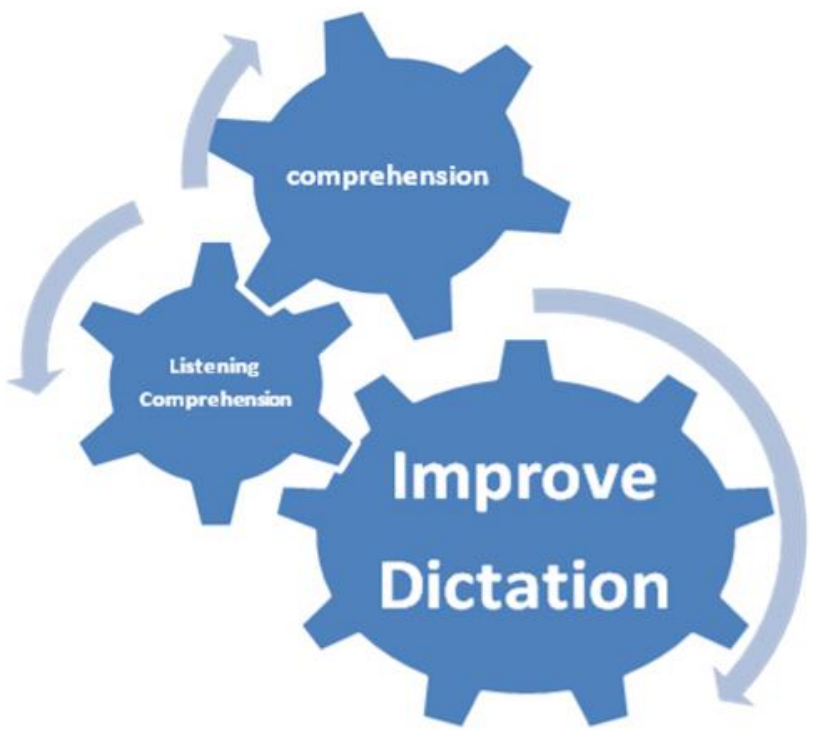

\section{Purpose of the study}

This paper is an attempt to investigate the place of listening comprehension in dictation of EFL learners and see whether the instruction of listening can improve dictation. In other words this study is to help Iranian students as EFL learners to have better comprehension of what is heard.

As Chastain (1988) states, one of the most crucial responsibilities of the teacher is to arouse the students' interest in the content of the listening comprehension. Hence, the central topic of this study is that the students can improve their listening ability if they are dictated something in which they are interested and comprehended.

\section{Participants}

The participants of this study were 80 sophomore Iranian EFL learners of Islamic Azad University, Sanandaj Branch. The participants were selected randomly from among those intact classes which had general English. Then they were divided into control and experimental groups randomly. The students of group $A$ (control) consisted of $37 \mathrm{EFL}$ students and group B (experimental) had 43 EFL students.

\section{Procedure}

In group A, dictation was taught traditionally; that is the teacher was able to hit the target and dead center. Unlike group $A$ in which students play the most important roles in learning dictation, in group B students were required to listen to the teachers' explicit explanation on the new comprehension and then do some decontextualized exercises individually.

In this approach, students are provided with comprehensible texts, which include certain listening. These texts would act as a trigger for the students' higher order thinking patterns to start practicing. They are required to read and process the given passages and thereby come up with their own generalizations about the Standard dictation. This way, students are actually involved in a problem-solving procedure whereby they look at each text as a problem to be solved in order to comprehend the idea of the passage and reach at a conclusion concerning.

In other words, they have to produce the new dictation mechanically without receiving sufficient input. Treatment lasted for a whole semester. At the end, a directed writing task was given to the students of both groups to see how well they could utilize the dictation they had been taught. This dictation task had three reasons:

Firstly, eliciting writing dictation from the students and secondly, it was devised to help them express their idea about the course; that is their reflection on listening. Students' dictation were corrected on the basis of ESL Composition Profile taken from Testing ESL Composition: A Practical Approach" by Jacobs et al., 1981 , p. 30. Thirdly, these technical terms are likely to pose the least threat to learners as most of words are randomly used and the percentage of the technical terms to estimate comprehension drastically.

\section{Results}

Table 1 represents means and standard deviations of the dictation exam for 2 groups of cases in pre- and posttests. The traditional group (group A) mean was 14.5 in the pre-test and increased to 15.32 in the post-test. In the modern group (group B) the dictation mean was 14.34 in the pre-test and increased to 16.80 in the post-test. The increasing in dictation scores in the modern group was higher than in the traditional group.
Sci.Technol.Edu.

CIndian Society for Education and Environment (iSee)
"Listening comprehension" http://www.indjst.org
P. Habibi et al. Indian J.Sci.Technol. 
Table 1.Means and standard deviations of dictation scores

\begin{tabular}{|l|l|l|l|l|}
\hline & \multicolumn{3}{|l|}{ Pre-test } & Post-test \\
\hline groups & $\mathrm{M}$ & $\mathrm{SD}$ & $\mathrm{M}$ & $\mathrm{SD}$ \\
\hline Traditional $(\mathrm{N}=50)$ & 14.50 & 2.452 & 15.32 & 2.428 \\
\hline Modern $(\mathrm{N}=50)$ & 14.34 & 2.775 & 16.80 & 1.841 \\
\hline
\end{tabular}

Equivalence of two groups' dictation means in the pre-test was examined by the independent t-test. The result $(t=0.306, d f=98, p=0.761>0.05)$ indicated that there was no significant difference between 2 groups in the pretest.

Table 2. The ANCOVA for the effect of different training on dictation scores

\begin{tabular}{|c|c|c|c|c|c|}
\hline Source & $\mathrm{F}$ & $\mathrm{df} 1$ & $\mathrm{df} 2$ & $\mathrm{P}$ & $\eta^{2}$ \\
\hline pre-test & 62.73 & 1 & 97 & 0.001 & 0.393 \\
\hline Group & 21.41 & 1 & 97 & 0.001 & 0.181 \\
\hline
\end{tabular}

The effects of pre-test and different training methods were analyzed based on the analysis of covariance (ANCOVA) and presented in Table 2. The results of ANCOVA indicate that there was a significant $(p<0.01)$ linear relationship between the pre-test and the post-test dictation scores. Moreover, the main effect of the group was significant in the post-test after controlling for the effect of the pre-test $(F=21.41, d f=1,97, P<0.01)$. Thus dictation scores differed significantly between the traditional and modern groups (controlling for the pre-test effect).

To compare the dependent variable in different groups, the Tukey's test was used and the results are displayed in Table 3. As seen in the Table 3, the adjusted mean of dictation scores in traditional group post-test was significantly less than the mean of the modern group. Consequently, it can be inferred that the modern training method leads to higher performance in dictation rather than the traditional method.

Table 3. Adjusted means and the Tukey's test for comparison

\begin{tabular}{|l|l|l|l|}
\hline group & M & SE & Tuckey's \\
\hline Traditional (1) & 15.28 & 0.239 & \multirow{2}{*}{$1<2$} \\
\hline Modern (2) & 16.84 & 0.239 & \\
\hline
\end{tabular}

Conclusion

The present study was conducted to determine whether listening comprehension has any impact on the students in Islamic Azad University, Sanandaj Branch. Regarding the main question of the study, results of this research shows that teaching dictation is more useful when directed at processing the comprehension by the students. Therefore, traditional approaches are not as useful as the processing examined processing listening comprehension here. On the other hand, dividing the students in two groups for joint activities would result in better of comprehension and motivated the less talented ones to learn new dictation presented through listening comprehension. Thus, the question of "whether dictation should be taught through listening comprehension" is affirmative since it has a direct impact on the improvement of dictation.

The improvement leads to the students' motivation and interest. Comprehension activities should have simultaneous listening skills. For instance, so long as students haven't found out how passive voice is constructed, they shouldn't be expected to use them in their dictations.

It is likely that most of these dictation teacher specialists, anxious to convert to dictation teachers, would have to take the training in areas of listening teaching skills as well as relevant comprehension information which the teacher does not presumably possess. Thus, within the domain of dictation, the teaching of listening skills presupposes study skills which require a comprehension to establish and validate spelling words. It is hoped that the present discussion has offered sufficient rationale to justify the position of a dictation teacher inside listening skill. It was tried to show the result graphically. It is shown that teaching dictation is more useful when directed at processing the listening comprehension by the students.

Unless dictation is meaningful for the students, they wouldn't be able to form properly in dictation processes. Dictation is made meaningful when it serves the logic behind presenting listening, semantic, syntactic, and pragmatic properties of language. So this research, not only emphasized a useful way of teaching listening comprehension in dictation, but also can be used $\mathrm{s}$ an effective method to improve the students spelling and dictating ability.

References

1. Anderson A and Lynch T (1988) Listening. Cambridge: CUP.

2. Bacon SM (1989) Listening for real in the foreign language classroom. Foreign Language Annuals. 22(4), 61-77.

3. Celce-Murcia M, Dornyei Z and Thurrel S (1997) Direct approaches in L2 instruction: a turning point in communicative language teaching. TESOL Quarterly. 31(1), 141-149,191.

4. Celce-Murcia M and Mclntosh L (Eds.) (1981) Teaching English as a Second or Foreign Language. Rowley, Ma.: Newbury House.

5. Chastain K (1988) Developing second language skills: Theory and practice. 3rd edition. San Diego, CA: Harcourt Brace Jovanovich.

6. Chaudron C and Richards CJ (1986) The effect of discourse markers on the comprehension of language. Appl. Linguistics. 7(21), 113-127.

7. Chiang CS (1995) The effects of speech modification, prior knowledge, and listening proficiency on lecture listening comprehension of Chinese EFL students. Modern English Teaching J. 78(2), 199-217.

8. Jacobs, L. et al. (1981).Testing ESL composition : a practical approach. Rowley, MA. : Newbury House.

9. Johnson K (1995) Language teaching and skill learning. Oxford: Basil Blacwe11.

10. Parrot M (1993) Tasks for Language Teachers: A Resource Book for Training and Development. Cambridge: CUP.

11. Rivers MW (1981) Teaching foreign language skills. Chicago: Univ. Chicago Press.
Sci.Technol.Edu.

Clndian Society for Education and Environment (iSee)
"Listening comprehension" http://www.indjst.org
P.Habibi et al. Indian J.Sci.Technol. 